\title{
Transposition
}

Musique et Sciences Sociales

9| 2021

Musique et sexualité

\section{Music and Erotic Agency - Sonic Resources and Social-Sexual Action}

\section{Tia DeNora}

\section{(2) OpenEdition}

1 Journals

\section{Electronic version}

URL: http://journals.openedition.org/transposition/6261

DOI: 10.4000/transposition.6261

ISSN: $2110-6134$

\section{Publisher}

CRAL - Centre de recherche sur les arts et le langage

\section{Electronic reference}

Tia DeNora, "Music and Erotic Agency - Sonic Resources and Social-Sexual Action", Transposition [Online], 9 | 2021, Online since 30 March 2021, connection on 23 April 2021. URL: http:// journals.openedition.org/transposition/6261 ; DOI: https://doi.org/10.4000/transposition.6261

This text was automatically generated on 23 April 2021

\section{(c) (†) (อ)}

La revue Transposition est mise à disposition selon les termes de la Licence Creative Commons Attribution - Partage dans les Mêmes Conditions 4.0 International. 


\title{
Music and Erotic Agency - Sonic Resources and Social-Sexual Action
}

\author{
Tia DeNora
}

\section{EDITOR'S NOTE}

Texte initialement publié dans Body \& Society, 3/2, 1997, p. 43-65.

(c) SAGE Publications (London, Thousand Oaks and New Delhi).

\section{AUTHOR'S NOTE}

Earlier versions and parts of this article were presented to the 1994 Annual Conference of the British Sociological Association (Preston), the $20^{\text {th }}$ Anniversary Conference of Social Theory Politics and the Arts (Baton Rouge), the LAMS Seminar, University of Milan, the 1996 American Sociological Association (New York), and the 1996 ISA RC 37 Committee Conference (Brussels). Thanks to Paul DiMaggio, Giampietro Gobo, Antoine Hennion, Alberto Melucci, Richard Peterson, Douglas Tudhope, Anna Lisa Tota, Gretchen Wheelock, Robert Witkin and Vera Zolberg for critical feedback.

\section{Culture into Agency}

\section{The Social Structure of Sexual Experience}

1 The erotic is one of the best available building sites for cultural constructivist theory because the emotions, pleasure and desire have consistently been brought to the fore in current sociocultural analysis. This attention arose as part of an effort to redress the often "disembodied" character of classic social theory ${ }^{3}$ and to address the historical, geographical and scenic specificities of sexual. ${ }^{4}$ Thanks to works like these, it is now commonplace for sexual activity to be theorized as something that takes shape in and 
through reference to culture - imageries, representations, metaphors, sexology manuals, narrative structures, medical and scientific classifications, and so on. Cultural materials are herein understood as providing possibilities for the "disciplinization" of bodies, hearts and minds to the extent that culture is understood to offer a range of (potentially contradictory) physical and emotional ways of being, sexual being included..$^{5}$

2 It is one thing to illuminate the cultural construction of sexual representations, and to allude to their constitutive role as "technologies" of gender. ${ }^{6}$ It is quite a different, and perhaps equally challenging, matter to describe how these representations actually "get into" and inform real lines of erotic conduct. What has been missing within sociocultural studies so far is a focus on the social, social-psychological and micropolitical processes through which desire and socially situated sexual action actually come to be culturally informed. ' Conversely, we also know little about how cultural forms come to be occupied by real-time residents. These matters are far from trivial: for real social actors - social analysts included - the idea that culture can be mobilized in ways that generate erotic agency is well known, albeit not necessarily in these specialist-analytic terms. In erotic play, in day dream and in more strategic forms of sexual conduct, actors can be seen clearly to mobilize culture; they (we) may resort to diverse images, scripts, values and ideas of all kinds in order to "do" being erotic and being sexual. In this respect, "passing" and "getting through" the erotic is similar to the accomplishment of any other scenic social activity. At times, these mobilizations are accompanied by considerable self-awareness; at other times, actors resort to particular cultural forms as a matter of practical action or routine. Whatever the level of reflexive awareness, culture clearly provides constituent ingredients for the configuration of (erotic) feeling, situations and agency.

How, then, do cultural forms get "under the skin" in ways that animate actors, "nature" and natural-social scenarios? And what, if any, are the limits of cultural construction?

4 A convenient entry into these issues as they apply to the social/physiological event of orgasm is supplied by Travers. ${ }^{8}$ Travers depicts orgasm as fraught with a peculiar kind of tension, one generated from an often conventional demand in sexual interaction for contradictory forms of sincerity - social versus bodily. On the one hand, sexual actors may be constrained by the need "to please" each other through the mutual communication of bodily (i.e. "natural") pleasure. ${ }^{9}$ To accomplish this "social" form of sincerity, actors employ a range of gestures and devices garnered from more and less conventional etiquettes and images of nature/pleasure. ${ }^{10}$ For example, they may feel obliged to enact preferred semblances of "dissolution of the self into bio-forces beyond its control" ${ }^{11}$ On the other hand, bodily sincerity, or "sincerity of the flesh" as Travers puts it - may not resemble culturally preferred and publicized images of sexual climax. Thus, Travers concludes, "a faked orgasm [i.e., one accompanied by canonic orgasmic insignia] is often more real than a real one", ${ }^{12}$ the "real" one being improperly socialized (and therefore not ceremonially pleasing but rather, socially insincere) when unaccompanied by canonic orgasmic insignia. These contradictory demands on the social and physical body are generated by physical versus social ceremonial forms of sincerity. This contradiction is perhaps an existential feature of (late 20th century?) "intimacy" - the need for (creatively misplaced?) trust because, as Travers puts it, "no matter how loud the cries, how inevitably accelerando the climax, how transported the 
facial features, there is no guarantee that all the signs are not empty, as in When Harry Met Sally". ${ }^{13}$ I now want to use and critique Travers's insights in order to move beyond what I regard as "weak" versions of cultural constructivism.

\section{Disentangling Culture, Nature and Agency}

5 By portraying the ceremonial features of sexual occasions, Travers's consideration of orgasm highlights some of the ways in which bodily processes and bodily responses are socially "disciplined", how the body and its activities may be structured and presented in ways that "live up to" social expectations, values and taboos. Just as Elias ${ }^{14}$ documented the disciplinization of a range of bodily minutiae, Travers points to sexual "climax" and sexual narrative as similarly socially disciplined. In this respect, he is not alone. ${ }^{15}$ In what follows, I suggest that a focus on bodily dramaturgy, and the cognitivist bias this project entails, unnecessarily juxtaposes the bodily and the social (as if the social merely "clothed" the body). Such a project is simply not bullish enough about culture's powers, it does not specify adequately what is meant by culture, nature or social agency and it cannot therefore examine the actual character of the interrelationship between these terms. To lay the groundwork for this "strong" theory, via musical examples, of how culture gets into action and "nature" and, conversely, how nature and culture are the achievements of social action, I attempt, in the next two sections to disentangle culture, nature and agency.

\section{Disentangling Culture and Agency}

lnteractionist perspectives on sexuality are sometimes criticized for failing to theorize the role of cultural and social structures and for failing to consider the social provenance of aesthetic structures such as, for example, sexual "scripts". ${ }^{16}$ This criticism is only partially correct. It imputes to interactionist conceptions far too much regard for "free" agency and it fails to appreciate the implicit structuralist character of many symbolic interactionist treatments of sexuality.

7 It is true that dramaturgical and other actor-centred approaches to sexuality do not usually consider the question of where particular sexual-cultural forms come from (e.g. where did the "twin-set and pearls" femininity to which Garfinkel's "Agnes" aspired actually come from? And who says orgasmic cries will be meaningful or "realistic" only if they involve accelerando, particular facial features or crescendo?). But it is not true that actor-centred approaches ignore the supra-individual features of culture. Indeed, their failure to develop the concept of culture derives less from a denial of culture than from an implicit tendency to presume cultural structures while at the same time failing to describe the mechanisms through which culture actually informs action. Culture, in other words, bears a great deal of weight in many actor-centred approaches, but it is rarely positioned in the limelight.

8 For example, the Goffmanian - and, on occasion, even the Garfinkelian - subject, is obliged to respect, realize and maintain the ceremonial order of a "normal, natural world", that is the world of social forms. As a case in point, Travers's depiction of social and sexual social agency dwells almost exclusively on the mobilization of preferred signs. It purports the acting subject as concerned with "getting it right" in terms of gesture, with "passing" and with being "pleasing". In sexual situations, for example, it 
may be polite and indeed expected, that one groan! Thus, what dramaturgical and some ethnomethodological accounts fail to address is also what structuralist and poststructuralist accounts themselves often omit: cultural innovation, challenge, resistance, change and - perhaps equally importantly - the ways in which what comes to pass as cultural "stasis" is a dynamic social achievement. ${ }^{17}$

These are important matters because cultures are never fully formed, never ineluctable, and therefore themselves topics of investigation and manipulation (just as it is political to depict "natural reality" so too it is political to make claims about "what a culture is". ${ }^{18}$ This point is underscored when the indexical properties of concepts, rules or conventions are recognized (Barnes 1982). If it is in and through practical instantiations that cultures and traditions are realized, then a space is left for creative forms of agency and, thus, for social and cultural challenge and change. As one commentator has put it, the Goffmanian, dramaturgically engaged subject is, "committed to the conventional order, not distanced from it". ${ }^{19}$ The focus of dramaturgical sociologies is therefore implicitly directed to actors as en-actors of the ceremonial.

10 Thus, culture is not the sole author of action. Dramaturgical perspectives may tell us about how culture disciplines action, but they celebrate cultural stability and underemphasize the ways in which cultures are often packed with tension. Dramaturgical perspectives are thus of little use for nuanced examinations of the dynamic quality of the culture-agency relationship, examinations that recognize the reflexive relationship between the ways that agents invoke and mobilize cultures and cultural forms themselves.

11 Indeed, the ability to be conscious of culture as something to be used, shaped and mobilized, and the ability to comment reflexively upon culture, implies that agents have degrees of distance from cultural resources. Recently these issues have been reinvigorated within the literature on "modernity". A range of commentators have suggested that the ability to stand askew from cultural forms, and to mobilize those forms deliberately in favour of specific activities, are cardinal features of late 20thcentury life ${ }^{20}$ though the historical nature of this claim has not gone unchallenged. ${ }^{21}$ This heightened reflexivity, and the often removed quality this reflexivity lends to realtime experience, is a function of the plurality and availability of (often contradictory) discourses that characterize the so-called "postmodern condition". "Simulation", "virtuality", "hyperrealism" - these terms index a purportedly modern form of symbolic mobility wherein an entry into a cultural form is like making a "trip". ${ }^{22}$ This mobility is itself viewed as a testimony to the heightened role played by culture and the imaginary in modern life.

12 In short, if we are to gain explanatory benefit from the idea of cultural construction as it occurs at the ground-level of social agency, then the study of how cultural forms "get into" action needs to be built upon a conception of agency and culture as distinct but reflexively linked. This reflexive linkage can be understood as occurring in two directions. First, in and through the ways that action mobilizes culture, it "fills in" or creatively elaborates the very forms that enable and constrain it. Second, a plurality of cultural forms may be available for action, and these forms may have contradictory implications for action's outcomes. The perception of this plurality, and the potential contradictions engendered by it, in turn lengthen the distance between actors and the cultural forms in and through which action is configured. 


\section{Disentangling Culture and Nature}

13 A similar type of reflexivity applies to the interrelationship of culture and nature. It can be illuminated by considering the limits of cultural constructivism. These limits need to be specified if the power of culture is to be fully investigated if we are to specify what it means to say that bodies and bodily processes are inextricable amalgams of nature/culture (as I do below by considering the ways in which culture may provide crucial ingredients or the organization of bodily processes). Thus, it is necessary to recover, albeit only temporarily, the now-often discarded culture/nature dichotomy.

Sexual action and bodily response can occur outside or askew from narratives and classification systems. That is, sexual experience may be meaningful to bodies without necessarily being meaningful to linguistic or imagistic consciousnesses. In a variety of ways, bodies and bodily sensation can and will exist outside of culture - bodies can warm, cool, exude, swell, feel pain or be itchy, and so on. These phenomena may be ascribed with a variety of meanings and they may remain meaningless, i.e. without socially recognized implication. ${ }^{23}$ Indeed, the non-linguistic materiality of sex - its specific sensual properties, such as smells or sounds - constitute some of its distinguishing features and may serve to sexualize otherwise non-sexual circumstances.

I am suggesting that the cultural construction of "culture/nature" is not, as is sometimes implied, a one-way process; on-cultural bodily materiality provides enabling/constraining resources for the generation of "new" cultural forms. This is true for sexual culture but also for many other forms of culture production. For example, in an earlier study ${ }^{24}$ I have discussed how Beethoven's bodily approach to the piano keyboard provided a somatic basis for his musical style. In a different context, I have also described how, within a culture of "alternative" contraceptive practice, material aspects of the fertile female body have been identified in ways that access them as "natural resources" for the articulation of gendered accounts of bodies, reproduction and sex. ${ }^{25}$ Similarly, others have described how the materiality of bodies can "disrupt" social relations and this disruption may provide space within which to resist a "given" cultural regime; ${ }^{26}$ particular bodies, in other words, do not only give rise to particular desires, they may also intrude on desire, whether actors' own or the desires of others. ${ }^{27}$ Indeed, the very point that cultural representations are political rests upon the assumption that representations interact with, and make demands on, their subjects in different and consequential ways. Cultural forms may configure nature, but they do so by marginalizing and ranking non-cultural features (e.g. of bodies). To speak of the "politics of representation" presumes, in other words, a negotiation between cultural forms and the subjects and materials to which these forms apply. This presumption implicitly rests on actors' real experiences of tension between culture and non-culture, between forms of culture and something else.

The point, then, is that culture is not totalizing in its disciplinary properties over nature; rather it facilitates the process of bringing semblances of the material body to life. Culture vivifies and disciplines the body, yes, but it does not create bodies ex nihilo. This point is illustrated clearly in the cultural history of anatomy. A number of distinguished scholars have recently demonstrated that anatomical classification systems have politics in and through the ways they discipline that counts as the body 
and its workings. ${ }^{28}$ Nowhere is this point more vividly illustrated than through the vicissitudes of the clitoris and its career in the annals of "orthodox" medical taxonomy. ${ }^{29}$ Nonetheless, and without denying the serious consequences of anatomical/cultural politics in this regard, women may experience sexual pleasure whether or not they have read Gray's Anatomy because (1) the body is more than a mere cipher and (2) because there are cultures of the body and bodily practice that do not owe their existence to public descriptors.

One does not, in other words, require adjectives - or, for that matter, concepts - for bodily experience, though cultures provide often robust, compelling resources for facilitating and organizing bodily experience and its perception. Bodies - not just actors - can act, and can do so in unruly, un-cultured ways; bodies are not just culture disciples and because of this, they may betray actors just as actors may betray bodies.

In short, "nature" - when it consists of unanticipated and undefined bodily manifestations - may provide resources for cultural discovery, for the creative production of new and "alternative" accounts of "how nature works". Indeed, this is the liberatory feature of culture; that new and "alternative" forms can be created and adapted in innovative ways, by individuals and collectivities. Cultures are living; they are public conveniences and as such can be tailored to the perceived exigencies of local, practical and material circumstances. The perception of the "reality" of these circumstances is never entirely dependent upon the viewpoints that cultures provide. To believe otherwise is to be a "cultural dope".

"Nature" has been recently disempowered within sociocultural theory. It has too often been reduced to an empty space, one merely awaiting cultural configuration, a mere "raw and pliable material" for meaning construction. It is as if so called "nature" were only knowable in and through culturally constructed forms. This position is crude and is well-illustrated by considering the erotic realm..$^{30}$ It is not currently popular to maintain that "nature constructs culture". To do so - to refer to bodily "realities" - is often viewed as dangerously essentialist, as leading away from or ignoring constructivist understanding. This need not be the case. The creation and mobilization of culture and its resulting "natural histories" may be structured by the specific material features of "nature" (nature may greet social actors without having been formally [culturally] introduced). Moreover, to maintain that culture constructs nature, without simultaneously maintaining the opposite, smuggles an unwarranted form of theoretical asymmetry into an otherwise useful understanding of nature and culture as reflexively linked. As Carole S. Vance suggested some time ago, we can and should incorporate, "bodily sensation and function into a social constructivist frame while still acknowledging that human experience of the body is always mediated by culture and subjectivity, and without elevating the body as deterministic". ${ }^{31}$

The human science should not be shy of the idea that there is an extra-cultural dimension to human social activity. Indeed, entertaining such a notion creates conceptual space within which to explore with far more nuance the interrelationship between culture, nature and agency. That relationship is currently (and oxymoronically) depicted as simultaneously too tight and too loose. It is too tight because it will not admit the possibility that action may escape discursive construction but may nonetheless be social (in ways that highlight the physicality, the animalsociality of human action). It is too loose because it is unable to retain a principle that cultural construction can apply not only to meaningful action, but to human 
physicality (e.g. the physiological human body) as well. If this statement appears paradoxical it is only because of social theory's current inability to conceive of culture as simultaneously more powerful and less ubiquitous than it is currently understood to be. One may be an agent without necessarily being a cultured agent because resources and structures for agency may derive from physical and environmental features of action's settings and from actors' bodies as these interact with settings. Bodily business may be transacted outside culture ("nature may inform culture") and also outside the modes of consciousness that culture generates. Conversely, the body and its business are both heightened and suppressed by culture; actors/bodies live up to cultural expectations and engage in the moral work of producing a "natural, normal world". Sexual bodies, like bodies in general, are thus neither full-time consumers of, nor fully consumed by, cultures. Cultures arise from bodies as much as vice versa. (Think, for example, of the links over time between "cuisine" and what historically/geographically located human bodies can chew, swallow, tolerate and digest.)

21 As Haraway 32 has suggested, the body can be usefully viewed as a cyborg ("cybernetic organism"), a compound of hybrid techno-organic embodiment and textuality. Bodily potentialities are made manifest through the ways they interact with the symbolic and material cultures that repress, liberate and otherwise discipline them. These configuration processes are rarely smooth, indeed they are mostly "lumpy" 33 because the cultural resources that discipline bodies are often inimical. But it is through these configuration processes that anatomy and physiology - as we know them - are assembled.

In sum, good constructivist theory can acknowledge material realities without hypostatizing them and without reverting to essentialism. The recognition of bodily realities only strengthens the power of constructivist paradigms, particularly when we can cite cases where bodies are culturally configured and where particular aspects of bodily reality are culturally suppressed. Culture clearly facilitates/constrains the transaction of bodily business; it constructs bodily reality to the extent that body and embodied action are reflexively oriented to the terms, models and structures culture provides. For example, how many individuals "know" their gallbladders in the ways they "know" their genitals? Because we have learned a range of conventional accounts for the latter-accounts which provide simultaneously a medium of surveillance - we mistakenly assume that there is less to know about the former (or that such knowledge is less accessible - even when they give us "trouble" we learn about our gallbladders through the intermediaries of X-rays, experts and scans). Thus, to tighten up the looseness of cultural constructivism, and to loosen up the tight bits, we need to accept that (1) even highly cultured, well-disciplined and vigilantly surveilled entities like genitals may "act" in ways that escape cultural frameworks, and (2) even un-cultured things like the gallbladder may be phenomenally amplified in and through the creation of culture. "Culture", then, is a resource for the realization of particular semblances or aspects of "nature", and, conversely, bodily materiality may provide a resource for culture creation.

Returning now to Travers's dramaturgical portrayal of the orgasm helps to clarify this point. Distinguishing, as Travers does, between the "real" (physiological) and "fake" (i.e. social) features of orgasm preempts investigation of the interaction between the semiotic and physiological body. The nature/culture distinction that dramaturgic considerations of the body preserve make it impossible to consider that bodies may in 
fact become the forms that depict them. It may, in other words, be sociologically disempowering to conceive of a non-interactive relationship between body and culture. Although culture is not the only resource for social and/or sexual agency (I have described above some of the ways that "nature" may intrude on social action in ways that lead to cultural innovation), culture and body may interact. Actors are often aware of the "uses" of culture and they often make and mobilize culture in ways that allow them to "get things done". Indeed, the culture/body dichotomy is precisely what actors are often attempting to bridge, either by trying to align nature with culture (e.g. through exercise or plastic surgery) or culture with nature (e.g. by engaging in activities to alter representations and conventions). In these ways, actors may be engaged routinely in the personal and social projects of establishing more intimate links between the bodily (their bodies) and the cultural. Culture is thus not only good to think with, it is something within which one can be a body of quality. Both in their technical details and in the responses that come to be associated with these details, cultural forms bear traces of bodies - the body, perhaps, but also particular bodies as these appear within "idiocultures". ${ }^{34}$ Bodies come alive and are configured through culture; indeed, sometimes, bodies can only be or do things when culture is there to help.

24 For example, in the now-classic piece, "Sensual Uncertainty, or Why the Clitoris is not Enough", Lynne Segal can be read as elaborating this theme. In autobiographical mode, Segal describes how the fantasies which she has always needed, "to come to orgasm, by any methods, are... tedious and obnoxious... I resent the effort I have to make to produce them, and the disconnection which occurs with lovers who, at least recently, are most caring, gentle and as extensively physically stimulating as I could wish" ${ }^{35}$ Segal describes the way in which, for her, culture (images and ideas) are part of an erotic technique of arousal and satiety. That is, fantasy is a device that generates explicit "fixations" for imaginative and real-time sexual processes. In this sense, then, culture is a "fix" and Segal, in these circumstances, a "culture addict" who needs the (what she considers to be) unwholesome cultural substance of masochistic imagery, without which she can't get to and through "orgasmic sex".

Both Travers and Segal show us how culture is "used" to accomplish sex. Both allude to how cultural materials - images ideas, and texts - are brought into the bedroom where they function, as they would in any other setting, as part of a "toolkit" 36 for social action, as a means or medium for the accomplishment of scenic (Travers) and bodily (Segal) specificity. Cultural materials - things from outside the real-time event provide cues and means for the organization of lines of conduct and bodily process. A focus on how culture gets into (sexual) action, therefore, is a focus not only on the semiotic and ethnomethodological "work" of sex, but also on the cultural creation of the body and thus, on body politics. In recognizing culture's limits (in relation to the nature and to agency), and that it may apply to social locations and actors with varying degrees of intensity, culture's constitutive and disciplinary powers are significantly extended into the realm of human physicality. Thus, finally, a theoretical foundation for a "strong" version of cultural construction has been established. In the remainder of this article I build upon this foundation by developing a theory of how culture, here specifically music, "gets into" and "composes" action, here erotic action. 


\section{Music and Aesthetic Agency}

How can music be examined for the ways in which it is implicated in the constitution of aesthetically reflexive subjects? When actors employ music in the context of erotic activity, to what extent can this resort to culture be understood as part of a process of constituting an aesthetic-erotic environment and a set of parameters (a partial predesign or stylistic signalling) for the organization of erotic interaction and its embodied beings? How is music a resource for the configuration of bodies/minds?

\section{Music as a Social "Force"}

There is a venerable tradition within musical theory that depicts music as active in the production of emotion, thought and conduct. From Plato's strictures against particular melodies to the Parents' Music Resource Center, ${ }^{37}$ the notion of musical affect is prominent. Because of its conventional and often repeated character (notated, orally or mechanically reproduced), music is a purposeful, though not necessarily instrumentalrational activity. Can bodies, then, be understood to pass through sonorous fields, and if so, how? Can music's "traces" be perceived in acting bodies? How, more specifically, do actors (and their bodies) use musical culture in real-time experience?

It seems obvious that music is effective (that for its listeners it is infused with affect), and that, at least on occasion, music channels action (to the extent that it is oriented to and articulated as meaningful). I have addressed this issue in earlier work ${ }^{38}$ using Willis's study of the "bikeboys". ${ }^{39}$ Willis describes how these boys thought of their music as emblematic of their non-musical cultural practices. For the bikeboys, music was not merely "representative" of professed values/acts. Rather, music was constitutive of social life in the sense that the boys referred to their music in order to create and enforce a way of life that was, "almost literally seen in the qualities of their preferred music". ${ }^{40}$

\section{Music and Temporality}

Within Bikeboy culture, music provided a cultural vehicle, a means of transport from one situation to another, a way of "getting through" a particular situation. To say that the Bikeboy's music provided a referent for a mode of activity, is to say that it provided a working or candidate model for the temporal/spatial ordering (coordinating) of the evening. For example, referring to a musical passage, an actor might say to another, "We'll go like this", or she/he might make use of music as metaphor to allude to a line or style of action (e.g. "faster", or "smoother", or "in unison"). The point here is that music provides non-propositional resources for collective (i.e. concerted) physical activity. For the Bikeboys, music provided a guide/model for how to move bodies (on/ off bikes). As with dance ${ }^{41}$ then, music can be understood as providing a referent to be taken up in and through bodily conduct. Music can thus provide a catalyst for body transformation (slow to fast, sitting or standing, standing to dancing, clipped to fluid and so on). Music is by no means the only referent for body transformation - one can also move "like treacle" or run "like the wind". Moreover, music - like treacle, wind and poetry, "makes nothing happen" (as Auden once put it), but is nonetheless, "a way of happening/a mouth". As a candidate way of happening, music (treacle, wind, poetry) 
provides models, means, motives, agendas and opportunities for ways of social and social-sexual happening.

For example, like other cultural materials ${ }^{42}$ music can provide resources for the articulation of temporal process. At a basic level, music can be used to measure time. (Toscanini's rendering of Mozart's overture to Le Nozze de Figaro is often described as the perfect egg-timer - if you want a very soft-boiled egg.) Music can also be used to map or mark the phenomenological experience of time's passage (for example, a "long time" can be turned into "no time at all" through the introduction of music). ${ }^{43}$ Musical translation of time occurs when music is perceived as providing a ground against which time's passing can be observed, (re)evaluated and (re)experienced. Through the ways time is musically "chunked", linear or serial time can be converted into cyclical time, time can be heard to be repeating itself, recoiling, retracting or retreating. It can also be understood as compressed or decompressed (e.g. "cut time" or "double time"). Music can make time "fly", it can make us "forget time" and it can also "drag time out". Music can also annul time: for example, Adorno ${ }^{44}$ considered Stravinsky's use of "primitive" rhythms (i.e. dance rhythms) degraded the time of the bourgeois subject through its abandonment of overarching rhythmic patterns in favour of sheer pulse. In Adorno's view, this was one aspect of the "sacrifice" of the subject which he so disdained in Stravinsky. In the celebration of the musical unit of the pulsating instant, historical structures and historical consciousness were forsaken. This, Adorno believed, led to the "forgetful" mindset that was the bedrock of the "ontological ideology".

\section{Specifying the "Music" of Sexual Action-Music as Metaphor}

31 I have described how music "chunks" and rechunks time and how actors may play or imaginatively replay music in ways that enable them to transcend other time claims. I have also alluded, via Willis ${ }^{45}$, to how music may be used to realign bodily activity (speed up/slow down the motion of bodies). These are examples of how music provides non-conceptual, non-verbal, non-pictorial resources for the constitution of agency. In them, music can be seen as a resource for producing activity that has narrative structure and timing. In these two senses, music provides technologies for the production of occasioned social realities.

Music may also be used as a metaphor or analogue for non-musical events, concepts and activities. For example, one might attempt to think "symphonically" or "contrapuntally". Or one might "trumpet" one's message. One might speak of "feminine" and "masculine" cadences (weak vs strong closure to the tonic key) or feminine and masculine themes, as is all too common in music commentary. One might also say that the music of Beethoven conveys, as Adrienne Rich once put it, "sexual messages". ${ }^{46}$ For Susan McClary, at least, Beethoven's characteristically powerful, boisterous and sometimes obsessive forms of musical closure (e.g. the finale of the Fifth Symphony) are phallocentric ${ }^{47}$ In all of these examples, music is being read - by social actors - as a metaphor, simulation or sublimation of social life. In the act of these readings, actors mobilize music as a resource for action, argument and for the constitution of social reality.

How social representations are inscribed into and read off from "disinterested" music is of course of considerable interest to analysts of culture. But it is important here that we do not treat these readings as resources, but rather consider them as members' 
accounts. To remain in our interpretive armchairs dictating claims about just what music metamorphoses is simply authoritarian, ${ }^{48}$ overlooking as it does the often rich diversity of cultural practice and consumption through which texts of all kinds are "made habitable". ${ }^{49}$ To claim for example, that Beethoven's music is "masculine" because it is "powerful" (i.e. loud, emphatic tutti finales) not only skips a logical step, it simultaneously grounds itself on unwarranted assumptions about the "nature" of the feminine. For these reasons, it is clearly turned away from the interactionist concern with the ways actors co-produce both themselves through objects and, conversely, produce objects through themselves.

Music is a key cultural resource for the disciplinization of body, emotion and action. It is a form of culture closely linked, through movement and dance, to body conduct. As with all forms of culture, however, its link to agency (and to the interpretations it inspires) is contingent upon local circumstances of use. Particular musics may conspire with or against particular bodies, they may constrain and/or enable particular desires and forms of conduct.

of sociological interest, then, is the question of how, with reference to musical forms, nature/culture amalgams are forged by real actors. To ask this question is simultaneously to ask about how music is a constituent ingredient in actors' productions of their agencies. In what follows, I suggest that we can do this not by considering whether music simulates erotic activity, but rather by considering how and when erotic activity simulates music. Can/do we (ever), for example, hear (feel? experience?) music in sex? To ask this question is to ask whether music and sex are ever or can ever be co-productive. To address these questions means that we need to consider much more closely what it means to say that music organizes the body. To do so is to examine Raymond Williams' proposition that:

rhythm is a way of transmitting a description of experience in, such a way that the experience is re-created in the person receiving it, not merely as an "abstraction" or an emotion but as a physical effect on the organism - on the blood, on the breathing, on the physical patterns of the brain... it is more than a metaphor; it is a physical experience as real as any other..$^{50}$

Issues like these can only be explored through qualitative studies of music and everyday life. They cannot be addressed through social theory alone. In the remainder of this article, draw on a few tentative examples of some of the myriad ways in which music may be used as a structuring device for erotic interaction. These examples should not be considered as ethnographic data (though an ethnographic investigation is currently ongoing); they are used only for the heuristic purpose of formulating topics and questions for the investigation of music-in-action.

\section{Music in Everyday Life - As Soundscape for Erotic Action}

37 Here are the musical-erotic experiences of four social actors, each of whom had been involved in at least one sexual situation where music played a constitutive, organizing role. All four of the accounts concern heterosexual encounters, all of which occurred at the male participant's dwelling. Perhaps unsurprisingly, therefore (but also in keeping with studies of gender and domestic technology), ${ }^{51}$ in each case, it was the male partner who selected the "background" music. 

generic activity structures into (and adapt according to) local sexual situations. Musical devices are thus resources (enabling/constraining) for the semiotic configuration of sex, just as they are resources for the configuration of other forms of agency (e.g. the long tradition of "songs for work", the semiotic repertoires of music for the film, the role of muzak in organizational culture). Musics provide materials with which actors 
may allude to styles and genres of activity. They also provide a means of contextualizing actors and of creating a "background" to which actors may relate in order to discipline, meaningful feeling and bodily form.

The fourth example, in which Ravels' Bolero was used as an accompaniment to erotic activity, illustrates, perhaps most clearly, the ways in which music may be used to discipline bodily conduct. This piece was composed in 1928 and it became, as Donald Grout once observed, "the musical equivalent of a bestseller". ${ }^{53}$ In the example relayed to me, it was put on the stereo as background music by a man in his early 20 s, the first time he and his partner (of the same age) had sexual intercourse. After the film 10 (and the British ice-skating duo Jane Torvill and Christopher Dean who skated to Bolero in the Olympic games), the choice may appear somewhat hackneyed,,$^{54}$ but this is precisely why it can also seem "correct". Bolero's highly publicized sexual and frankly coital associations thus brought to the foreground music as a simulation of sex. Indeed, in choosing it as "background" music, the male partner in the example I have been discussing was proposing it as a model for sex in the sense that activity and desire were inserted into the narrative form it offered. The piece played an overt role in the process of occasioning.

It is worth developing this example for its heuristic value, in order to consider how music (whether heard in real time or remembered) may provide a ground or candidate model for structuring the incarnate practices of erotic conduct. The piece begins quietly, sustains a regularly repeated pulse throughout and rises steadily to a crescendo. The same melody is reiterated throughout and is stated initially by solo flute (an upper-range instrument conventionally associated by both "expert" and "lay" listeners with both "pure" and "open" tone colour and also an instrument typically used to register the feminine in music - the silvery gurgling of water, as in the opening of Smetana's Moldau, or delicate bird song as in Beethoven's Pastoral symphony, or languor, as in Debussy's Prélude à l'après-midi d'un faune). The melody is played in the flute's (and flautist's) most relaxed-sounding, "coolest" lower register, in the key of C, beginning on the $\mathrm{C}$ above middle $\mathrm{C}$ and ending on middle $\mathrm{C}$, the instrument's lowest note. ${ }^{55}$ Ravel intended the piece to sound like a pipe organ, growing steadily louder as stops are pulled out. The lower brass instruments are the last to enter and the use of glissando (tonal sliding) in the upper-register trombone plays a special role in that it introduces, frankly, the sexualized body by introducing a particular kind of "grain". ${ }^{56}$ Glissandi are, within the discourse of "classical" music, often construed as "unclean" that is, as part of different and "less tasteful" musical discourses (such as jazz). At the approaching climax of this piece, then, preferred and dispreferred discourses come to be melded together. Earlier in the work, the way is paved for this liminality by the saxophone, an instrument outside the traditional "classical music" orchestra. The work ends abruptly after its tonal apex is reached.

As an icon of erotic temporality, Bolero can stand for the tone, pacing and duration for the real time sexual event. The work lasts about 15 minutes. Is 15 minutes "long enough"? "Too long"? And for whom? One might argue ${ }^{57}$ that, for a man in his early 20s, the 15-minute format of the piece provided a device for prolonging the event. Bolero retranslated the young man's bodily tempo in ways that slowed it down. One could also argue that for the woman, the piece made a statement about the shape and content of the sexual event. For example, the ineluctable quality of its melody may have provided a means of holding her in, symbolically, to the regular thrust of what the 
man defined as the "sexual event". In this sense, music can come to carry moralstylistic force, though it would be un-useful to posit this force as deterministic, as McClary has at times implied with reference to, for example, Beethoven. These matters cannot be "read in to" real life events but must be seen in the interaction and/or its accounts.

\section{The Musical Construction of Physiological Response}

Music's role as an active ingredient in social formation may also at times encompass the physiological body itself. That is, the physical body can itself be a semiotic achievement and music provides one set of cultural materials for that kind of semiotic work. For these reasons, the question of how people negotiate "background music" for sex may be an important part of the study of the politics of sexual pleasure.

For example, music may inspire and interact with physical-cultural practices, in ways that Dyer alludes to in his personal responses to disco, pop and rock $^{58}$ and their relation to "scene culture". Dyer suggests that rock's "repeated phrases keep you in their relentless push" whereas pop is "disembodied" - about psychological yearning rather than bodily activity, and disco is "whole body" in the sense that it implies sinuous movement as opposed to sheer thrust. It is of course key to underline that these musical "forces" are only activated in and through the ways that users (listeners, dancers, sexual actors) interact with musical forms.

Musics may also provide resources for synchronizing embodied action, as in dance, by imposing/offering narrative structures on/for that action. These first two forms of musical disciplinization are illustrated in the Bolero example discussed above. They concern bodily conduct. But music may enlist bodies in ways that may at times come to discipline not just conduct, but, more profoundly, the quantity and quality of physiological responses as well. For example, it may be reasonable to suggest that orgasms can be "musically constructed", if music provides structures into which actors' perceptions of their bodies are translated and which, in turn, establish non-cognitive forms of "bio-feedback" that come to structure body sensation. ${ }^{59}$ Here music provides structural materials for the psychological sources of sensation, its phenomenological features such that the experience of sexual sensation itself can be understood as "musically composed". This is to say that the physical-cultural practices of body conduct that emerge from human-music interaction affect bodily sensation and physiological response (e.g. bodies - not just actors - may imitate and fall into musical rhythms and textures in ways that heighten or suppress sensations).

Music is by no means unique as a medium for the reconstruction of bodily materiality. That culture can construct or reconstruct physiology is increasingly recognized by alternative approaches to pain management and medical treatment (e.g. visualization, bio-feedback) where culture's structuring capacity is employed strategically to alter body perception. For example, with visualization, patients learn how to align their awareness of the "painful" phenomenon with an image. This activity relieves pain (or lowers blood pressure) by translating it into different imagistic terms..$^{60}$ This process recontextualizes the pain in ways that reconfigure it as "something else".

51 There is clearly a parallel to be drawn here with Becker's classic work on marijuana use. ${ }^{61}$ As Becker puts it, the drug's so-called "effect" is something that, "emerges from an interaction between culture and chemistry". One has to learn categories for 
perceiving the drug's effects. One enters into a symbolic world of categories that construct "getting high". The "drug" then, is culture/cannabis.

Lynda Birke has suggested that:

what you are now - your biological body - is a product of complex transformations between biology and experiences in your past. And these transformations happening now will affect any such transformations in the future. Biology, in this view, does have a role: but it is neither a base to build on nor determining. ${ }^{62}$

Culture, through the ways it interacts with the body, may heighten or bring into focus both body and bodily experience. To say this is not to deny the materiality of the body (e.g. erection, lubrication, the emission of semen and so on), but it is to admit, at the very least, that whatever comes to count as "evidence" of a "bodily event" (even when we are dealing with a body's testimony to itself) is a matter of cultural construction and, at the most, that, as Birke puts it, ${ }^{63}$ materiality itself is a hybrid of nature/culture.

\section{Conclusion}

To be sure, music is, as Richard Leppert has put it, "a well-practised device for the production of desire". ${ }^{64}$ The question of just what, at the level of lived desire and erotic conduct, this statement actually means has been under-explored. The point of this article has been to initiate a discussion on this neglected topic and, to pave the way for a "strong" cultural constructivist position by disentangling agency, culture and nature (while at the same time appreciating the irreflexive links).

As a form of textual time and textual architecture, music provides non-propositional, non-depictive terms through which physiological processes can be perceived. Played in either real time, memory or imagination it can provide parameters through which and into which sexual response is shaped. It can provide a way of marking sexual time. Examining human-music interaction provides a clear entry into the question of how culture/nature amalgams are actually put together over time and space and how agency is configured with reference often reflexive to aesthetic forms.

Music can thus be employed in ways that enable/constrain (and establish claims about) the shape and duration of sexual activity. It provides just one of the potentially wide range of resources for action and experience, one which can be mobilized with varying degrees of deliberation. Music is, moreover, a resource, an often under-acknowledged resource, one that can easily slip past rational awareness but nevertheless engage the body. These are practical matters and they require further investigatiom..$^{65}$ Music's role in the configuration of agency has, as I have attempted to describe, implications for sexual differences (individual differences and generic-class differences) between participants (in both heterosexual and homosexual encounters) and in this respect, it is potentially sexual-political. The constitutive role of cultural resources such as music may, moreover, have special salience in non-intimate sexual partnerships where, as with mechanical modes of production in factories, offices, sites and classrooms, generic parameters provide crucial resources for coordination and expectation.

In short, questions about how music is used in erotic situations, how foregrounded/ backgrounded it is, and the peculiarly modern use of electronically reproduced music (CD player, personal stereo, muzak and so on) are all potentially informative for the historically changing character and the politics of "intimacy". There are many issues concerning human-music interaction that should be explored and they will add 
considerably to our knowledge of how culture "gets into" action. Simultaneously the profile of socio-music studies will be significantly heightened when we can at last begin to explain what it means to speak of music's "power".

\section{BIBLIOGRAPHY}

ADAM Barbara, Time and Social Theory, Cambridge, Polity, 1991.

ADORNo Theodor, Philosophy of Modern Music, New York, Seabury Press, 1974.

BAKER Mark, The Parents' Music Resource Center: Symbolic Conflict Amidst Structural Decay in the United States, unpublished Ph. D. Dissertation, Department of Sociology, University of Exeter, 1994. BARNES Barry and LOYAL Steven, “'Agency' as a Red Herring in Social Theory”, Philosophy of the Social Sciences, 31/4, 2001, p. 507-524.

BARNES Barry, "On the Extensions of Concepts and the Growth of Knowledge", Sociological Review, 30/1, 1982, p. 23-44.

BARTHES Roland, The Responsibility of Forms: Critical Essays on Music, Art and Representation, trans. Richard Howard, New York, Hill and Wang, 1985.

BARTKY Sandra, Femininity and Domination, London, Routledge, 1990.

BAUDRILLARD Jean, Simulations, New York, Semiotext(e), 1983.

BECKER Howard S., “On Becoming a Marijuana User”, American Journal of Sociology, 59/2, 1953, p. $35-42$.

BETTERTON Rosemary, Looking On: Images of Femininity in the Visual Arts and Media, London, Pandora, 1987.

BIRKE Lynda, "In Pursuit of Difference: Scientific Studies of Men and Women”, KIRKUP Gill and KELLER Laurie Smith (eds.), Inventing Women: Science, Technology and Gender, Cambridge, Polity, 1992, p. 81-102.

BIRKE Lynda, “Transforming Biology”, CROWLEY Helen and HIMMELWEIT Suzann (eds), Knowing Women: Feminism and Knowledge, Cambridge, Polity, 1992, p. 66-77.

BOURDIEU Pierre, Distinction: A Social Critique of the Judgement of Taste, Cambridge, Polity, 1984.

CERTEAU Michel de, The Practice of Everyday Life, Berkley and London, University of California Press, 1984.

COWARD Rosalind, Female desire, London, Paladin Grafton Books, 1984.

DENORA Tia, "From Physiology to Feminism: Reconfiguring Body, Gender and Expertise in Natural Fertility Control", International Sociology, 11/3, 1996, p. 359-383.

DENORA Tia, "How is Extra-musical Meaning Possible? Music as a Space and Place for 'work", Sociological Theory, 2/2, 1986, p. 84-94. 
DENORA Tia, “The Musical Composition of Reality? Music, Social Action and Reflexivity", Sociological Review, May 1995, p. 296-315.

DENORA Tia, Beethoven and the Construction of Genius: Musical Politics in Vienna 1792-1803, Berkeley and London, University of California Press, 1995.

DOUGLAS Mary, "Reconstituting the Cosmos", paper presented to the International Conference on De-traditionalization: Authority and Self in an Age of Cultural Uncertainty, Lancaster University, 8-10 July, 1993.

DYER Richard, “In Defense of Disco", FRITH Simon and GOODWIN Andrew (eds), On Record: Rock, Pop and the Written Word, London, Routledge, 1990, p. 410-418.

ELIAS Norbert, The Civilising Process, Vol. 1: The History of Manners, Oxford, Blackwell, 1939.

FEATHERSTONE Mike, HEPWORTH Mike and TURNER Bryan S. (eds), The Body: Social Process and Cultural Theory, London, Sage, 1991.

FINE Gary Alan, "Idioculture and Little League Baseball”, American Sociological Review, 44, 1986, p. 733-745.

fOUCAUlT Michel, The History of Sexuality, Vols 1 and 2, Harmondsworth, Penguin, 1981 and 1987. FRISBY David, Fragments of Modernity, Cambridge, Polity, 1985.

GAGNON John and SIMON William, Sexual Conduct: The Social Source of Human Sexuality, Chicago, Aldine, 1973.

GARDETTO Darlainer, "The Social Construction of the Female Orgasm", paper presented to the American Sociological Association, Atlanta (Georgia), August 1988.

GIDDENS Anthony, Modernity and Self-Identity, Cambridge, Polity, 1991.

GIDDENS Anthony, The Consequences of Modernity, Cambridge, Polity, 1990.

GREENBERg David, The Construction of Homosexuality, Chicago, University of Chicago Press, 1988.

GROUT Donald J., A History of Western Music, New York, Norton, 1973.

HALl Lesley A., Hidden Anxieties: Male Sexuality, 1900-1950, Cambridge, Polity, 1991.

HARAWAY Donna, "A Manifesto for Cyborgs: Science, Technology and Socialist Feminism in the 1980s", Socialist Review, 80, 1985, p. 65-107.

HAYS Sharon, "Agency and Structure and the Sticky Problem of Culture", Sociological Theory, 12/1, 1994, p. 57-72.

HILBERT Richard, “Anomie and the Moral Regulation of Reality: The Durkheimian Tradition in Modem Relief", Sociological Theory, 4/1, 1986, p. 1-19.

HILBERT Richard, “The Acultural Dimensions of Chronic Pain: Flawed Reality Construction and the Problem of Meaning", Social Problems, 31, 1984, p. 365-378.

Holland Janet, RAMAZANOGLu Carolyn, SHARPE Sue and THOMSON Rachel, "Power and Desire: The Embodiment of Female Sexuality", Feminist Review, 46, 1994, p. 21-38.

IRIGARAY Luce, “This Sex Which Is Not One”, MARKS Elaine and COURTIVRON Isabelle de (eds), New French Feminisms: An Anthology, London, Schocken, 1980.

IRVINE Janice M., Disorders of Desire: Sex and Gender in Modem American Sexology, Philadelphia, Temple University Press, 1990. 
JACKSON Stevi and MOORES Shaun (eds), The Politics of Domestic Consumption: Critical Readings, London: Harvester Wheatsheaf, 1995.

JACKSON Stevi, “Even Sociologists Fall in Love”, Sociology, 27/2, 1993, p. 201-220.

JACKSON Stevi, “Heterosexuality as a Problem for Feminist Theory”, Richardson Diane (ed.)

Theorizing Heterosexuality, Milton Keynes, Open University Press, 1996, p. 20-38.

JACKSON Stevi, Childhood and Sexuality, Oxford, Basil Blackwell, 1982.

JACKSON Stevi, On the Social Construction of Female Sexuality, London, Women's Research and Resources Centre, 1978.

JACOBUS Mary, Keller Evelyn Fox and SHutTLEWorth Sally (eds), Body/Politics: Women and the Discourses of Science, London, Routledge, 1990.

JEFFREYS Sheila, Anti-Climax: A Feminist Perspective on the Sexual Revolution, London, The Women's Press, 1990.

LAQUEUR Thomas, Making Sex: Body and Gender from the Greeks to Freud, Cambridge, Harvard University Press, 1990.

LASH Scott and URRY John, Economies of Signs and Space, London, Sage, 1993.

LAURENTIS Teresa de, Technologies of Gender, Bloomington, Indiana University Press, 1987.

LEPPERT Richard, The Sight of Sound: Music, Representation and the History of the Body, Berkeley and London, University of California, 1993.

MCCLARY Susan, Feminine Endings: Music, Gender and Sexuality, Minneapolis, University of Minnesota Press, 1991.

MOORE Lisa Jean and CLARKE Adele E., "Clitoral Conventions: Twentieth-Century Anatomical Representations", Feminist Studies, 21/2, 1995, p. 255-301.

PLUMMER Ken, Sexual Stigma: An Interactionist Account, London, Routledge, 1975.

RAKUSEN Jill, "Relationships and Sexuality", PHILLIPS Angela and RAKUSEN Jill (eds), The New Our Bodies Ourselves, $2^{\text {nd }}$ British ed., Harmondsworth: Penguin, 1989, p. 11-270.

RICH Adrienne, “Compulsory Heterosexuality and Lesbian Existence”, Signs, 5/4, 1980, p. 631-660. SEGAL Lynne, "Sensual Uncertainty, or Why the Clitoris is not Enough", CARTLEDGE Sue and RYAN Joanna (eds), Sex \& Love, London, The Women's Press, 1983, p. 30-47.

SEIDMAN Steven, Embattled Eros: Sexual Politics and Ethics in Contemporary America, London, Routledge, 1992.

SHARMA Ursula, "Bringing the Body Back into the (Social) Action. Techniques of the Body and the (Cultural) Imagination", Department of Sociology and Social Anthropology, University of Keele, 1996.

SIMON William and GAGNON John H., "Sexual Scripts", Society, 22, 1984, p. 53-60.

SMITH Dorothy, Texts, Facts and Femininity: Exploring the Relations of Ruling, London, Routledge, 1990. SNITOW Ann, STAMSELL Christine and THOMPSON Sharon (eds), Desire: The Politics of Sexuality, London, Virago, 1984.

SWIDLER Ann, “Culture in Action”, American Sociological Review, 51, 1986, p. 273-286.

THOMAS Helen (ed.), Dance, Gender and Culture, London, Macmillan, 1993. 
TRAVERS Andrew, “An Essay on Self and Camp”, Theory, Culture \& Society, 10/1, 1993, p. 127-143.

TROTTER Robert T. and CHAVIRA Juan Antonio, Curanderismo: Mexican American Folk Healing, Athens, University of Georgia Press, 1981.

TUDHOPE Douglas, TAYLOR Carl and BEYNON-DAVIES Paul, “Taxinomic Distance, Classification and Navigation", Proceedings of the International Conference on Interactivity and Hypermedia in Museums, San Diego, October 1995.

TURNER Bryan, The Body and Society, Oxford, Blackwell, 1984.

URRY John, The Tourist Gaze, London, Sage, 1990.

VANCE Carole S., "Social Construction Theory: Problems in the History of Sexuality", CROWLEY Helen and HIMmeLWEIT Suzann (eds), Knowing Women, Milton Keynes, Open University Press, 1992, p. 132-145.

WALBy Sylvia, Theorizing Patriarchy, Oxford, Blackwells, 1990.

WEEKS Jeffrey, Sex, Politics and Society: The Regulation of Sexuality since 1800, London, Longman, 1981. WEEKS Jeffrey, Sexuality and Discontents: Meanings, Myths and Modern Sexualities, London, Routledge, 1985.

WILLIAMS Raymond, The Long Revolution, London, Cox and Wyman, 1961.

WILLIS Paul, Profane Culture, London, Routledge and Kegan Paul, 1978.

WITKIN Robert and DENORA Tia, “Art as social agency”, paper presented to the American Sociological Association, Washington DC, August 1995.

WITKIN Robert, Art and Social Structure, Cambridge, Polity, 1995.

WITKIN Robert, The Intelligence of Feeling, London, Heinemann, 1974.

\section{NOTES}

1. WITKIN Robert and DENORA Tia, "Art as social agency", paper presented to the American Sociological Association, Washington DC, August 1995.

2. DENORA Tia, "The Musical Composition of Reality? Music, Social Action and Reflexivity", Sociological Review, May 1995, p. 296-315.

3. TURNER Bryan, The Body and Society, Oxford, Blackwell, 1984; FEATHERSTONE Mike, HEPWORTH Mike and TURNER Bryan S. (eds), The Body: Social Process and Cultural Theory, London, Sage, 1991.

4. GAGNON John and SIMON William, Sexual Conduct: The Social Source of Human Sexuality, Chicago, Aldine, 1973; Plummer Ken, Sexual Stigma: An Interactionist Account, London, Routledge, 1975; JACKSON Stevi, On the Social Construction of Female Sexuality, London, Women's Research and Resources Centre, 1978; JACKSON Stevi, Childhood and Sexuality, Oxford, Basil Blackwell, 1982; Foucault Michel, The History of Sexuality, Vols 1 and 2, Harmondsworth, Penguin, 1981 and 1987; WEEKS Jeffrey, Sex, Politics and Society: The Regulation of Sexuality since 1800, London, Longman, 1981; WEEKS Jeffrey, Sexuality and Discontents: Meanings, Myths and Modern Sexualites, London, Routledge, 1985; SIMON William and GAGNON John H., "Sexual Scripts", Society, 22, 1984, p. 53-60; SNITOW Ann, STANSEll Christine and THOMPSON Sharon (eds), Desire: The Politics of Sexuality, London, Virago, 1984; GREENBERG David, The Construction of Homosexuality, Chicago, University of Chicago Press, 1988; SEIDMAN Steven, Embattled Eros: Sexual Politics and Ethics in Contemporary America, London, Routledge, 1992. 
5. COWARD Rosalind, Female desire, London, Paladin Grafton Books, 1984; BETTERTON Rosemary, Looking On: Images of Femininity in the Visual Arts and Media, London, Pandora, 1987; LAURENTIS Teresa DE, Technologies of Gender, Bloomington, Indiana University Press, 1987; RAKUSEN Jill, "Relationships and Sexuality", PHILLIPS Angela and RAKUSEN Jill (eds), The New Our Bodies Ourselves, $2^{\text {nd }}$ British ed, Harmondsworth: Penguin, 1989, p. 11-270; IRVINE Janice M., Disorders of Desire: Sex and Gender in Modem American Sexology, Philadelphia, Temple University Press, 1990; BARTKY Sandra, Femininity and Domination, London, Routledge, 1990; HALL Lesley A., Hidden Anxieties: Male Sexuality, 1900-1950, Cambridge, Polity, 1991; BIRKE Lynda, "In Pursuit of Difference: Scientific Studies of Men and Women", KIRKUP Gill and KELLER Laurie Smith (eds.), Inventing Women: Science, Technology and Gender, Cambridge, Polity, 1992, p. 81-102; BIRKE Lynda, “Transforming Biology", CROWLEY Helen and HIMMELWEIT Suzann (eds), Knowing Women: Feminism and Knowledge, Cambridge, Polity, 1992, p. 66-77; LAQUEUR Thomas, Making Sex: Body and Gender from the Greeks to Freud, Cambridge, Harvard University Press, 1990; JACKSON Stevi, "Heterosexuality as a Problem for Feminist Theory", Richardson Diane (ed.) Theorizing Heterosexuality, Milton Keynes, Open University Press, 1996, p. 20-38; JEFFREYS Sheila, Anti-Climax: A Feminist Perspective on the Sexual Revolution, London, The Women's Press, 1990.

6. LAURENTIS, Technologies of Gender.

7. See JACKSON Stevi, "Even Sociologists Fall in Love", Sociology, 27/2, 1993, p. 201-220, on this point.

8. TRAVERS Andrew, “An Essay on Self and Camp”, Theory, Culture \& Society, 10/1, 1993, p. 127-143.

9. Here Travers's portrayal of sexual action coincides with Simon and Gagnon's notion of "cultural Scenarios" (SIMON and GAGNON, "Sexual Scripts").

10. Of course these gestures also serve as orientational devices and facilitate the mutual tuning in process of (sexual) interaction; they are one sort of building material for the construction of shared social space and time.

11. TRAVERS, "An Essay on Self and Camp", p. 137.

12. Ibid.

13. Ibid.

14. ELIAS Norbert, The Civilising Process, Vol. 1: The History of Manners, Oxford, Blackwell, 1939.

15. See GARDETTO Darlainer, "The Social Construction of the Female Orgasm", paper presented to the American Sociological Association, Atlanta (Georgia), August 1988.

16. See, e.g., WALBY Sylvia, Theorizing Patriarchy, Oxford, Blackwells, 1990, p. 115.

17. HAYS Sharon, "Agency and Structure and the Sticky Problem of Culture", Sociological Theory, 12/1, 1994, p. 57-72; BARNES Barry and LOYAL Steven, “'Agency' as a Red Herring in Social Theory”, Philosophy of the Social Sciences, 31/4, 2001, p. 507-524.

18. BARNES Barry, "On the Extensions of Concepts and the Growth of Knowledge", Sociological Review, 30/1, 1982, p. 23-44; BOURDIEU Pierre, Distinction: A Social Critique of the Judgement of Taste, Cambridge, Polity, 1984; TUDHOPE Douglas, TAYLOR Carl and BEYNON-DAVIES Paul, "Taxinomic Distance, Classification and Navigation", Proceedings of the International Conference on Interactivity and Hypermedia in Museums, San Diego, October 1995.

19. WITKIN Robert, Art and Social Structure, Cambridge, Polity, 1995, p. 183.

20. GIDDENS Anthony, The Consequences of Modernity, Cambridge, Polity, 1990; GIDDENS Anthony, Modernity and Self-Identity, Cambridge, Polity, 1991; BAUDRILLARD Jean, Simulations, New York, Semiotext(e), 1983; LASH Scott and URRY John, Economies of Signs and Space, London, Sage, 1993; WITKIN, Art and Social Structure.

21. DOUGLAS Mary, "Reconstituting the Cosmos", paper presented to the International Conference on De-traditionalization: Authority and Self in an Age of Cultural Uncertainty, Lancaster University, 8-10 July 1993. 
22. URRY John, The Tourist Gaze, London, Sage, 1990; FRISBY David, Fragments of Modernity, Cambridge, Polity, 1985; LASH and URRY, Economies of Signs and Space.

23. HILBERT Richard, "The Acultural Dimensions of Chronic Pain: Flawed Reality Construction and the Problem of Meaning”, Social Problems, 31, 1984, p. 365-378; HILBERT Richard, “Anomie and the Moral Regulation of Reality: The Durkheimian Tradition in Modem Relief", Sociological Theory, 4/1, 1986, p. 1-19.

24. DENORA Tia, Beethoven and the Construction of Genius: Musical Politics in Vienna 1792-1803, Berkley and London, University of California Press, 1995.

25. DENORA Tia, "From Physiology to Feminism: Reconfiguring Body, Gender and Expertise in Natural Fertility Control", International Sociology, 11/3, 1996, p. 359-383.

26. Holland Janet, RAMAZANoglu Carolyn, SHARPe Sue and THOMSON Rachel, "Power and Desire: The Embodiment of Female Sexuality", Feminist Review, 46, 1994, p. 23.

27. Ibid.

28. JACOBus Mary, KELLER Evelyn Fox and SHUTTLEWORTH Sally (eds), Body/Politics: Women and the Discourses of Science, London, Routledge, 1990.

29. MOORE Lisa Jean and CLARKE Adele E., "Clitoral Conventions: Twentieth-Century Anatomical Representations", Feminist Studies, 21/2, 1995, p. 255-301.

30. So far, a space for "nature" has been reserved within social theory only by certain postLacanian, "gynocentric" feminist such as Luce Irigaray in This Sex Which Is Not One (1980). But in Irigaray's work, the "nature" of the female body is hypostatized. Irigaray conflates bodily materiality with bodily meaning (i.e. the feminine imaginary) in order to articulate ontological characteristics of female sexuality. She does not problematize the very anatomical categories from which her account of that sexuality is derived.

31. VANCE Carole S., "Social Construction Theory: Problems in the History of Sexuality", CROWLEY Helen and HIMMELWEIT Suzann (eds), Knowing Women, Milton Keynes, Open University Press, 1992, p. 140.

32. HARAWAY Donna, “A Manifesto for Cyborgs: Science, Technology and Socialist Feminism in the 1980s", Socialist Review, 80, 1985, p. 65-107.

33. Ibid.

34. FINE Gary Alan, "Idioculture and Little League Baseball”, American Sociological Review, 44, 1986, p. 733-745.

35. SEGAL Lynne, "Sensual Uncertainty, or Why the Clitoris is not Enough", CARTLEDGE Sue and RYAN Joanna (eds), Sex \& Love, London, The Women's Press, 1983, p. 42.

36. SWIDLER Ann, "Culture in Action", American Sociological Review, 51, 1986, p. 273-286.

37. BAKER Mark, The Parents' Music Resource Center: Symbolic Conflict Amidst Structural Decay in the United States, unpublished PhD Dissertation, Department of Sociology, University of Exeter, 1994.

38. DENORA, "The Musical Composition of Reality? Music, Social Action and Reflexivity".

39. WILLIS Paul, Profane Culture, London, Routledge and Kegan Paul, 1978.

40. Ibid., p. 63, emphasis in original.

41. thomas Helen (ed.), Dance, Gender and Culture, London, Macmillan, 1993.

42. ADAM Barbara, Time and Social Theory, Cambridge, Polity, 1991.

43. DENORA, "The Musical Composition of Reality? Music, Social Action and Reflexivity".

44. ADORNo Theodor, Philosophy of Modern Music, New York, Seabury Press, 1974.

45. WILLIS, Profane Culture.

46. RICH Adrienne, "Compulsory Heterosexuality and Lesbian Existence", Signs, 5/4, 1980, p. 631-660. Quoted in MCCLARY Susan, Feminine Endings: Music, Gender and Sexuality, Minneapolis, University of Minnesota Press, 1991, p. 129.

47. MCCLARY, Feminine Endings. 
48. DENORA Tia, "How is Extra-musical Meaning Possible? Music as a Space and Place for "work", Sociological Theory, 2/2, 1986, p. 84-94; DENORA, "The Musical Composition of Reality? Music, Social Action and Reflexivity".

49. CERTEAU Michel de, The Practice of Everyday Life, Berkeley and London, University of California Press, 1984.

50. WILliams Raymond, The Long Revolution, London, Cox and Wyman, 1961, p. 66-69; quoted in MCCLARY, Feminine Endings, p. 23.

51. JACKSON Stevi and MOORES Shaun (eds), The Politics of Domestic Consumption: Critical Readings, London: Harvester Wheatsheaf, 1995.

52. Written in 1921, Wozzeck is an atonal work. It is about an imperial Austrian army soldier who is subjected to sadistic treatment by his army doctor and captain. He lives with a "licentious" woman who deceives him with a drum major. On discovering this, he stabs her and then drowns himself.

53. GROUT Donald J., A History of Western Music, New York, Norton, 1973 p. 658.

54. A 1994 Valentine's Day issue of Cue magazine published a series of responses to the question, "What music gets you in the mood for... [sex]?" and listed the first names and ages of respondents. One, "Colm, age 22" said, "Ravel's Bolero. Never fails. Actually that's not true. It never fails in theory. The practice is another story. Put it this way, for everyone apart from me it never seems to fail, so I'd recommend it. But maybe I should recommend something else to myself because it's not getting me anywhere" (p. 70-71). Thanks to Elizabeth York for bringing this article to my attention.

55. Professional model flutes usually have a "B key" as well, so that their lowest note is B natural. But the instrument is understood to be "in the key of $C$ " that is, the most natural scale pattern that can be played, with one finger being lifted after the other (thus shortening the pipe) is the scale of C major. The "B key" is mainly added to give tonal depth to the lower register.

56. BARTHES Roland, The Responsibility of Forms: Critical Essays on Music, Art and Representation, trans. Richard Howard, New York, Hill and Wang, 1985.

57. Thanks to a member of the audience in the BSA conference session on aesthetics and sexuality, Preston, 1994.

58. DYER Richard, "In Defense of Disco", FRITH Simon and GOODWIN Andrew (eds), On Record: Rock, Pop and the Written Word, London, Routledge, 1990, p. 410-418.

59. When I presented this paper at the 1994 Social Theory, Politics and the Arts conference in Baton Rouge I was told of yet another, perhaps far more obsessive, example of this "Bolero phenomenon": a man who took pleasure in coordinating his own sexual climax with the musical climax in the work.

60. TROTTER Robert T. and CHAVIRA Juan Antonio, Curanderismo: Mexican American Folk Healing, Athens, University of Georgia Press, 1981; SHARMA Ursula, "Bringing the Body Back into the (Social) Action. Techniques of the Body and the (Cultural) Imagination", Department of Sociology and Social Anthropology, University of Keele, 1996.

61. BECKER Howard S., “On Becoming a Marijuana User”, American Journal of Sociology, 59/2, 1953, p. 35-42.

62. BIRKE, "In Pursuit of Difference: Scientific Studies of Men and Women", p. 75.

63. BIRKE, "Transforming Biology".

64. LEPPERT Richard, The Sight of Sound: Music, Representation and the History of the Body, Berkeley and London, University of California, 1993, p. 7.

65. We need to consider, for example, how actors "switch on or in" to music and we need to consider the degree of consciousness with which music as erotic technology is mobilized (e.g. the less deliberation, the more likely actors are being mobilized by [as opposed to mobilizing] cultures, the more likely they are enactors). 


\section{ABSTRACTS}

How does the cultural configuration of being and body happen? Just how are cultural products mobilized and how do texts, images, sonic structures and representations inform and thereby "get into" action? These are key questions for cultural studies, sociology and social psychology. They have so far not been addressed head on, and they by no means entail a mere "empirical implementation" of an otherwise already complete theorization of agency. In this article, I suggest that a good theory of agency can be developed through specific considerations of particular social realms, and with reference always to particular cultural materials. To this end, after some initial theoretical clarification of the links between culture, nature and social agency, I focus on the erotic, in order to pursue a more general concern with the interrelationship of expressive media and social agency. ${ }^{1}$ More specifically, I consider the question of how erotic agency maybe "musically composed", by which I mean how agency may take shape with reference to musical media.

Comment l'être et le corps se nouent-ils dans une configuration culturelle? Comment les produits culturels sont-ils mobilisés, et comment les textes, les images, les structures et les représentations sonores « entrent-elles en action » ? Ce sont là des questions fondamentales pour les études culturelles, la sociologie et la psychologie sociale. Pourtant elles n'ont guère été abordées de front jusqu'ici, et elles ne sauraient faire l'objet d'une " mise à l'épreuve empirique » à partir d'une théorisation de l'agentivité déjà complète. Cet article suggère que l'on peut développer une bonne théorie de l'agentivité en observant des milieux sociaux et des matériaux culturels particuliers. Dans ce but, après quelques considérations théoriques sur les liens entre culture, nature et agentivité sociale, je pars de la question érotique pour développer un propos plus général sur la relation entre les moyens expressifs et l'agentivité sociale. Plus spécifiquement, je me penche sur la question de comment l'agentivité érotique peut être « composée musicalement », c'est-à-dire comment l'agentivité peut se déployer par des moyens musicaux.

\section{AUTHOR}

\section{TIA DENORA}

Tia DeNora's initial studies were in music and sociology at West Chester University in Southeastern Pennsylvania. She completed her PhD in Sociology in 1989 at the University of California San Diego. From then until 1992, she worked at University of Wales Cardiff (where she was a University of Wales Fellow from 1989-91). She moved to Exeter in 1992 where she is currently Professor of Socioogy of Music. DeNora has been a Fellow of the Yale Center for Cultural Sociology since 2004 and recently was elected Fellow of the British Academy. She has served as Chair of the ESA Network on Arts Sociology and on various councils of learned societies, editorial boards and the 2008/2014 national Research Excellence Framework sub-panel for Sociology. With Gary Ansdell, she currently co-edits the Routledge Series on Music \& Change: Ecological Perspectives. Her publications include Beethoven and the construction of genius: musical politics in Vienna 1792-1803 (University of California Press, 1995), Music in everyday life (Cambridge University Press, 2000), After Adorno: rethinking music sociology (Cambridge University Press, 2003), Music-in-action: essays in sonic ecology (Ashgate, 2011), Music asylums: wellbeing through music in 
everyday life (Ashgate, 2013), and Making sense of reality: culture and perception in everyday life (Sage, 2014). 